\title{
LEGAL APPROACHES TO ONLINE ARBITRATION: OPPORTUNITIES AND CHALLENGES IN INDONESIA*
}

\author{
Elza Syarief $^{* *}$, Rina Shahriyani Shahrullah ${ }^{* * *}$, and Agustina Fitrianingrum ${ }^{* * * *}$ \\ Bagian Hukum Bisnis, Fakultas Hukum, Universitas Internasional Batam,Batam \\ Jalan Gajah Mada, Sei Ladi, Kota Batam, Provinsi Kepulauan Riau 29442
}

\begin{abstract}
Online arbitration is one of the mechanisms to settle business disputes. Using online arbitration in Indonesia is challenging because the Indonesian arbitration law (Law No.30 of 1999 concerning Arbitration and Alternative Dispute Resolution) does not specifically deal with online arbitration. This research provides arguments and evidences that the relevant Indonesian national laws support the use of online arbitration. It adopts a normative legal research with a qualitative approach. It is concluded that business people should not be doubtful to use online arbitration to settle their business disputes since it is valid and its awards are enforceable in Indonesia.
\end{abstract}

Keywords: online arbitration, business, Indonesia.

\section{Intisari}

Penggunaan elektronik dan internet dalam bisnis memberikan banyak peluang bagi pelaku bisnis untuk memperluas jaringan bisnisnya. Arbitrase online merupakan salah satu mekanisme yang memberikan alternative solusi ketika terjadi perselisihan dalam bisnis. Namun, pelaku bisnis akan menghadapi berbagai tantangan dalam menggunakan arbitrase online di Indonesia karena hukum arbitrase di Indonesia yang diatur dalam Undang-Undang No.30 Tahun 1999 tentang Arbitrase dan Alternatif Penyelesaian Sengketa tidak secara khusus mengatur hal-hal yang menyangkut arbitrase online. Penelitian ini bertujuan untuk memberikan dasar pemikiran bukti pendukung terkait bahwa hukum di Indonesia juga mendukung pelaksanaan arbitrase online. Penelitian ini menggunakan pendekatan hukum normatif dengan metode kualitatif digunakan untuk mengalisa hukum di Indonesia yang relevan. Hasil penelitian ini menyimpulkan bahwa pelaku bisnis seharusnya tidak perlu merasa khawatir menggunakan arbitrase online untuk menyelesaikan sengketa bisnis karena hasil keputusan arbitrase online jelas dan dapat dieksekusi di Indonesia.

Kata Kunci: arbitrase online, bisnis, Indonesia.

\section{Pokok Muatan}

A. Background 315

B. Research Methods

C. Research Findings and Analysis

D. Conclusion

This paper is part of research funded by the Directorate General of Higher Education of Indonesia (DIKTI) under Hibah Fundamental, Grant 2015-2016.

** Author correspondence: elzasyarief@elzalaw.co.id.

*** Author correspondence: rina@uib.ac.id.

***** Author correspondence: agustina@uib.ac.id. 


\section{A. Background}

Business is a means to improve a country's economic growth, ${ }^{1}$ therefore Indonesia as a developing country should encourage their nationals to actively participate in business activities nationally, regionally and internationally. However, business engagements do not always run smoothly. Disagreements among business people may occur at any time and these may result in legal disputes. ${ }^{2}$ Arbitration has become the most popular dispute resolution among business people because of its unique characteristics, such as less formal ${ }^{3}$, proceedings are usually private, ${ }^{4}$ the confidentiality of disputes is generally assured. ${ }^{5}$ More importantly, arbitral awards are enforceable in Indonesia under Law No.30 of 1999 concerning Arbitration and Alternative Dispute Resolutions. In addition, international (foreign) arbitral awards may be enforced in Indonesia since this country has ratified Convention on the Recognition and Enforcement of Foreign Arbitral Awards 1958 (the New York Convention $)^{6}$ through Presidential Decree No.34 of 1981 (Keputusan Presiden No.34 Tahun 1981).

Arbitration as defined by Bagheri constitutes 'a consensual process executed in a judicial manner whereby a dispute between two or more persons is finally resolved by an arbitrator's decision'? Similarly, Sidik Suraputra contends that arbitration constitutes a dispute resolution mechanism selected by parties in order to obtain a final and binding award that is decided by impartial arbitrators chosen by the parties. ${ }^{8}$ These definitions point out that arbitration is a private method $^{9}$ of solving disputes since it is conducted by private persons (arbitrators). ${ }^{10}$

Today, developed technology has penetrated business transactions. Electronic commerce and the use of Internet offer unprecedented opportunities for business people to expand their businesses. ${ }^{11}$ Similar to off-line businesses, E-commerce transactions may result in E-disputes; consequently it should be resolved by E-dispute resolution mechanism. Online arbitration is one of the dispute settlement mechanisms which can be utilized by business people. Those who engage in businesses may also use online arbitration to settle their disputes even though their business transactions are off-line. This is because online arbitration can transcend national boundaries, accordingly online arbitration fits for international business engagements. Other advantages of online arbitrations are as follows:

Table 1. Advantages of Online Arbitration

\begin{tabular}{lll}
\hline No. $\begin{array}{c}\text { Type of } \\
\text { Advantages }\end{array}$ & \multicolumn{1}{c}{ Descriptions } \\
\hline 1. Neutrality & $\begin{array}{l}\text { The Internet is a neutral place for } \\
\text { the disputing parties. }\end{array}$ \\
\hline 2. & Less costly & $\begin{array}{l}\text { The parties and arbitrators do not } \\
\text { have to travel for the hearings in } \\
\text { online arbitration. }\end{array}$ \\
\hline 3. Flexibility & $\begin{array}{l}\text { Audio and video conferencing } \\
\text { capability allows the parties to } \\
\text { conduct meetings and hearings } \\
\text { remotely. }\end{array}$ \\
\hline 4. Time Saving & $\begin{array}{l}\text { The parties will be able to initiate } \\
\text { and defend a claim by accessing } \\
\text { a Website and complete forms } \\
\text { electronically forms for the process } \\
\text { of arbitration. }\end{array}$ \\
\hline
\end{tabular}

R.F Saragih, 1999, Hukum dan Pembangunan, Lembaga Alternatif Penyelesaian Sengketa, Utomo, Bandung.

Sally A Harpole, "Factors Affecting the Growth (or Lack Thereof) of Arbitration in the Asia Region", Journal of International Arbitration, Vol. 20, No. 1, 2003.

Ronald Fitch, 1989, Commercial Arbitration in the Australian Construction Industry, The Federation Press, New South Wales. Compared with Klaus Peter Berger, 2000, Understanding International Commercial Arbitration, Kluwer Law International, Hague.

Tony Budidjaja, "Public Policy As Grounds of Recognition and Enforcement Of Foreign Arbitral Awards In Indonesia 154: the General Elucidation to Law of the Republic of Indonesia No.30 of 1999 concerning Arbitration and Alternative Disputes Resolution”, 2002. Convention on the Recognition and Enforcement of Foreign Arbitral Awards.

Mahmood Bagheri, 2000, International Contracts and National Economic Regulation: Dispute and Resolution Through International Commercial Arbitration, Kluwer Law International, Hague.

C S T Kansil, et al., 2005, Hukum Perusahaan Indonesia Aspek Hukum dalam Ekonomi, Pradnya Paramitha, Jakarta.

Edward Leahy, et al., "The Changing Face of International Arbitration", Journal of International Arbitration, Vol. 17, No. 4, 2000.

Pieter Sanders, 1975, Appeals Procedure in Arbitration' in International Commercial Arbitration, Documents and Collected Papers (19741975).

11 Marc Wilikens, Marc, et al., "Out-of-Court Dispute Settlement Systems For E-Commerce”, Paper, 20 th April 2000. 
5. Efficiency Web-based document filing systems will help the parties to submit many documents instantly and over any distance.

6. More Submissions can be archived by Convenient automated document management systems and could be reviewed from any location, at any time.

Source: Yüksel A.E.B,2007.

On 12 August 1999 the Indonesian Government enacted Law No. 30 of 1999 concerning Arbitration and Alternative Dispute Resolutions (Undang-Undang Republik Indonesia Nomor 30 Tahun 1999 tentang Arbitrase dan Alternatif Penyelesaian Sengketa) to complete all of the regulations concerning arbitration in Indonesia. This Law not only deals with arbitration but also governs other types of alternative dispute resolution such as consultation, negotiation, mediation conciliation, and expert assessment. The Law contains 82 Articles which are divided into eleven chapters as follows:

Table 2. Chapters of Law No. 30 of 1999 concerning Arbitration and Alternative Dispute Resolutions

\begin{tabular}{cl}
\hline Chapter & \multicolumn{1}{c}{ Title } \\
\hline I & General Provisions \\
II & Alternative Dispute Resolution \\
III & $\begin{array}{l}\text { Terms of Arbitration, Appointment of Arbi- } \\
\text { trators, and Right of Refusal }\end{array}$ \\
IV & $\begin{array}{l}\text { Procedure Applicable Before the Arbitration } \\
\\
\text { Tribunal }\end{array}$ \\
V & The Arbitration Opinion and Award \\
VI & Enforcement of Arbitration Awards \\
VII & Nullification of Arbitration Awards \\
VIII & Completion of the Arbitrators' Task \\
IX & Arbitration Fees \\
X & Transitional Provisions \\
XI & Closing Provisions \\
\hline
\end{tabular}

Source: Law No.30 of 1999

In addition to Law No.30 of 1999 concerning Arbitration and Alternative Dispute Resolution, Law No. 11 of 2008 concerning Electronic Information and Transactions is also the legal base for online arbitration. This Law was enacted to respond to the development of information technology and communications. The General Elucidation of this Law clearly emphasizes that "information Technology becomes a double-edged sword, that is to give contributions to the improvement of human welfare, advance, and civilization, and at the same time, becomes effective means for unlawful acts". The enactment of this Law was also driven by the realization that "electronic transactions for trade via electronic systems (electronic commerce) have made a part of national and international trade. This fact shows that the convergence in the field of information technology, media, and informatics (telematics), inevitably, keeps developing in line with the invention in the field of information technology, media, and communications".

Law No. 11 of 2008 concerning Electronic Information and Transactions consists of 13 chapters as follows:

Table 3. Chapters of Law No. 11 of 2008 concerning Electronic Information and Transactions

\begin{tabular}{|c|c|}
\hline Chapter & Title \\
\hline I & General Provisions \\
\hline II & Principles and Objectives \\
\hline III & $\begin{array}{l}\text { Electronic Information, Records, and } \\
\text { Signatures }\end{array}$ \\
\hline IV & $\begin{array}{l}\text { Provision of Electronic Certification and } \\
\text { Electronic Systems }\end{array}$ \\
\hline $\mathrm{V}$ & Electronic Transactions \\
\hline VI & $\begin{array}{l}\text { Domain Names, Intellectual Property Rights } \\
\text { and Protection of Privacy Rights }\end{array}$ \\
\hline VII & Prohibited Acts \\
\hline VIII & Dispute Resolution \\
\hline IX & $\begin{array}{l}\text { Role of the Government and Role of the } \\
\text { Public }\end{array}$ \\
\hline $\mathrm{X}$ & Investigation \\
\hline XI & Penal Provisions \\
\hline XII & Transitional Provisions \\
\hline XIII & Concluding Provisions \\
\hline
\end{tabular}

Source: Law No.11 of 2008.

Despite of online arbitration advantages as stated previously, the legality and validity of online arbitration in Indonesia are questionable because Law No.30 of 1999 concerning Arbitration and Alternative Dispute Resolutions does not specifically govern online arbitration. Hence, this 
research aims to examine the applicability of online arbitration based on Law No.30 of 1999 concerning Arbitration and Alternative Dispute Resolutions. In addition, Law No. 11 of 2008 concerning Electronic Information and Transactions is also used to support Law No.30 of 1999 to clarify the meaning and the use of electronic requirement in online arbitration

\section{B. Research Methods}

This research adopts a normative legal research method which is also known as a doctrinal method $^{12}$ because this type of research has the hermeneutic character. The hermeneutic character is defined as the process of changing from something that unknown to be known and understand. ${ }^{13}$ In this regard, this research proposes a broader interpretation of Law No.30 of 1999 concerning Arbitration and Alternative Dispute Resolutions and combines it with the application of Law No.11 of 2008 concerning Electronic Information and Transactions in order support the applicability and validity of online arbitration in Indonesia.

A normative legal research is also known as a study of documents because it relies mostly on secondary data such as legal theories, regulations, court decisions and doctrines. ${ }^{14}$ Hence, this object of this research (i.e. the primary legal materials) is Law No.30 of 1999 concerning Arbitration and Alternative Dispute Resolutions and Law No.11 of 2008 concerning Electronic Information and Transactions. To support the primary legal material, the research also utilizes secondary legal materials such as journal, books, and internet-based sources. The secondary data is examined and analyzed by using a qualitative approach.

\section{Research Findings and Analysis}

The scope of arbitration may be divided into three phases as follows: Phase 1: Prior to arbitral proceedings. A number of issues arise in this stage, for example, the capacity of parties to enter into an arbitration agreement, the existence and validity of the arbitration agreement, the enforceability of the arbitration agreement, and so forth. ${ }^{15}$ Phase 2: During arbitral proceedings. The issues may embrace the power of arbitrators to settle disputes, the representation and the legal assistance, the basic standards of due process in arbitral proceedings, the issuance of awards, and so forth. ${ }^{16}$ Phase 3: Post-arbitral proceedings. The issues may cover the recognition and enforcement of arbitral awards, the law governing the recognition and enforcement process, the formal conditions and the procedures of the recognition and enforcement proceedings, and so forth.

This research particularly focuses on three main issues, namely the validity of online arbitration agreement, the process of online arbitration hearing and the enforceability of online arbitration award.

Online arbitration is not specifically governed by Law No.30 of 1999 concerning Arbitration and Alternative Dispute Resolutions, hence it is questioned whether provisions under this Law are adequate to support the applicability and validity of online arbitration. Article 1 (1), arbitration means "a method of settling civil disputes outside the general courts, based on an arbitration agreement made in writing by the parties to the dispute". This provision merely emphasizes that arbitration settles the disputes outside of the general court jurisdiction without stating that the methods of conducting the arbitration processes. It is clear here that the definition of arbitration under Article 1 (1) of Law No. 30 of 1999 can be interpreted wider to cover traditional and online arbitration. Since online arbitration utilizes technology via internet, emails, online conferencing and so forth, the definition of online arbitration is "a method

\footnotetext{
Amiruddin, 2004, Pengantar Metode Penelitian Hukum, Raja Grafindo Press, Jakarta.

Eugenius Sumaryono, 1993, Hermeneutik Sebuah Metode Filsafat, Kanisius Yogyakarta.

Topo Santoso, 2005, Penulisan Proposal Penelitian Hukum Normatif, Fakultas Hukum Universitas Indonesia, Depok.

Hans Smit, et al., 2000, Commercial Arbitration: An International Bibliography (2nd revised and expanded edition).

Ibid.
} 
of dispute resolution that has all activities of the arbitration, including submissions to the arbitral tribunal and all proceedings, take place over the Internet via networks, e-mail, chat groups, or online conferencing". ${ }^{17}$

Article 1(1) of Law No.30 of 1999 emphasizes that arbitration can only be conducted if the disputing parties agree to arbitrate which is proved by their arbitration agreement. It is questioned whether online agreement to arbitrate has a legal standing under Law No.30 of 1999. Prior to examine the validity of online arbitration agreement, it is significant to state the substance of Article 4(2) of Law No.30 of 1999. This provision strictly requires that "the agreement to resolve disputes through arbitration as specified in paragraph (1) must be contained in a document signed by the parties". In other words, the arbitration agreement shall be in writing and signed by the disputing pasties. The question is whether these requirements can be fulfilled by online arbitration agreement.

The requirement in writing is met by online arbitration since Article 4(3) of Law No.30 of 1999 stipulates that "if an agreement is made to resolve a dispute by an exchange of letters, the sending of telexes, telegrams, faxes, e-mails, or any other form of communication must be accompanied by a record of receipt by the parties". This provision permit e-mails to evidence the written form of arbitration agreement. The other requirement is the signature of disputing parties on the arbitration agreement. The use of electronic signatures in an arbitration agreement is valid since Article 11 of Law No. 11 of 2008 concerning Electronic Information and Transactions states that (1) Electronic Signatures shall have lawful legal force and legal effect to the extent satisfying the following requirements:

a. Electronic Signature-creation data shall be associated only with the Signatories/ Signers;

b. Electronic Signature-creation data at the time the electronic signing process shall be only in the power of the Signatories/Signers;

c. Any alteration in Electronic Signatures that occur after the signing time is knowable;

d. Any alteration in Electronic Information associated with the Electronic Signatures after the signing time is knowable;

e. There are certain methods adopted to identify the identity of the Signatories/ Signers; and

f. There are certain methods to demonstrate that the Signatories/Signers have given consent to the associated Electronic Information.

Based on this provision, it is clear that electronic signatures have an equal position to manual signatures in general, with legal force and legal effect. Based on the explanations above, it can be defined that online arbitration agreement is an agreement made by the disputing parties through medium of technology to settle their dispute in arbitration.

Online arbitration agreement is the legal base to conduct an online arbitration hearing. Online arbitration hearing can be fully conducted by using the electronic means, such as hearing witnesses via video conferences ${ }^{18}$ "where each participant to arbitration sits before sound and video camera equipment. On the screen the faces of the other participants appear". ${ }^{19}$ Another method of conducting arbitration hearing is by transmitting documents electronically as long as the parties have the right of equal access to the information. ${ }^{20}$ Since, arbitrators do not physically meet, then another issue arises pertaining to at the seat of arbitration. It is very significant to arbitrators who conduct online

\footnotetext{
17 Jasna Arsic, "International Commercial Arbitration on the Internet: Has the Future Come Too Early ?", Journal of International Arbitration, 1997; Armağan Ebru Bozkurt YÜKSEL, "Online International Arbitration”, Ankara Law Review, Vol. 4, No.1, Summer, 2007.

18 Jasna Arsic, "International Commercial Arbitration on the Internet: Has the Future Come Too Early ?", Journal of International Arbitration, 1997.

19 Armağan Ebru Bozkurt YÜKSEL, “Online International Arbitration”, Ankara Law Review, Vol. 4, No.1, Summer, 2007.

20 Richard Hill, "On-line Arbitration: Issues and Solutions", Journal of International Arbitration, Vol. 15, 1999.
} 
hearings and proceedings to ascertain the seat or arbitration because it will determine "the nationality of the award and the jurisdiction of local courts for setting aside the award". ${ }^{21}$

There shall not be any problem if the disputing parties have determined the seat of arbitration prior to the hearings and proceedings. In this circumstance, the arbitrators only state the seat of arbitration in the award itself. ${ }^{22}$ However, if the seat of arbitration has not been determined by the disputing parties, the question is how to determine the seat of arbitration. The answer to this question is provided by Article 31(3) of Law No.30 of 1999 which stipulates that "If the parties have chosen an arbitration procedure, as contemplated in paragraph (1) they must agree on provisions for the timeframe and venue of the arbitration, and if the timeframe and venue are not determined, the arbitrator or arbitration panel will determine them".

Based on the explanations above, it should be noted here that there are no provisions of Law No.30 of 1999 prohibiting online arbitration proceedings and hearings as long as they are conducted based on the principle of equality, transparency and due process. The most determinative phase in the context of arbitration is the recognition and enforcement of arbitration awards ${ }^{23}$ because the awards have no legal effect in the absence of the recognition and enforcement of the awards, and the other phases of arbitration processes such as arbitration proceedings and the issuance of arbitration awards become meaningless. Winning parties also feel frustrated because they have incurred monies and time for arbitration, but their awards cannot be realized. ${ }^{24}$ The question is whether online arbitration awards can be enforced similarly as traditional arbitration awards. It should be noted here that arbitrators do not have executory power to recognize and enforce online arbitration awards that they have made. As a result, the process of recognition and enforcement of the awards must be performed by the courts of enforcing states according to their laws that govern such process.

Law No.30 of 1999 divides arbitration awards into two categories, namely domestic (national) arbitration awards and international (foreign) arbitration awards. Arbitration awards are categorized as domestic (national) arbitration awards if the proceedings and the seat of arbitration are in the jurisdiction of Indonesia. Article 1(9) of Law No.30 of 1999 defines international (foreign) arbitration award as "an award handed down by an arbitration institution or individual arbitrator outside the jurisdiction of the Republic of Indonesia, or an award by an arbitration institution or individual arbitrator which, under the provisions of Indonesian law, is deemed to be an international arbitration award". The question arises how to categorize online arbitration awards when all processes of arbitration are conducted online. As previously mentioned, that the seat of arbitration determines the nationality of arbitration, therefore the nationality of online arbitration awards is also depended on the seat of arbitration written in the awards.

As previously stated that online arbitration awards can only be enforced by the courts of enforcing states according to their laws that govern such process. In Indonesia, the enforcement of online domestic arbitration awards is governed by Article 59(1) of Law No.30 of 1999 which states that "within 30 (thirty) days from the date the award is rendered, the original text or an authentic copy of the arbitration award must be delivered to the Clerk of the District Court and registered there by the arbitrator or his/her/its proxy". Article 59(4) of Law No.30 of 1999 stipulates that "non-fulfilment of the provisions contemplated in paragraph (1) above will render the arbitration award unenforceable".

\footnotetext{
21 Nicolas De Witt, “Online International Arbitration: Nine Issues Crucial To Its Success”, The American Review Of International Arbitration, 2001.

22 Isabelle Manevy, “Online Dispute Resolution: What Future?”, http://www.juriscom.net/uni/mem/17/odr01.pdf, accessed 20 August 2015.

23 Okezie Chukwumerije, “Choice of Law in International Commercial Arbitration”, Journal of International Marketing, Vol. 3 , No. 2 , 1995.

24 Sudargo Gautama, “Arbitrase Kamar Dagang Internasional”, Paper, Raker Pertamina, Jakarta, 14 Oktober 1975.
} 
Based on these provisions, it is clear that Law No.30 of 1999 requires online arbitration awards to be printed and signed by the arbitrators. It is then clear that all phases of arbitration can be conducted online in Indonesia, but the last phase namely the enforcement of arbitration awards shall be conducted by using traditional approach, that is to print the online arbitration awards and have the arbitrators sign them.

\section{Conclusion}

The advantages of online arbitration may give opportunities to business people to settle their disputes less costly, more flexible, convenient and efficient because of the time saving and at the same time the neutrality of online arbitration is also guaranteed. However, the validity of online arbitration and the enforceability of online arbitration awards may be doubted by business people in Indonesia because Law No.30 of 1999 concerning Arbitration and Alternative Dispute Resolution does not specifically govern online arbitration.
Based on the examination of Law No.30 of 1999 concerning Arbitration and Alternative Dispute Resolutions, it is obvious that this Law should be interpreted wider to cover traditional and online arbitration. The issue of online agreement is resolved by Article 4(3) of Law No.30 of 1999 which permits the use of emails or any other form of communication. This provision is also supported by Article 11 of Law No. 11 of 2008 concerning Electronic Information and Transactions which clearly states that electronic signatures shall have lawful legal force and legal effect. In addition, there are no provisions of Law No.30 of 1999 prohibiting online arbitration proceedings and hearings as long as they are conducted based on the principle of equality, transparency and due process. More importantly, the enforceability of online arbitration awards should not become an issue since online arbitration awards can be printed and signed by the arbitrators. Overall, it can be concluded that online arbitration in Indonesia can be utilized by business people since the relevant Indonesian laws support the use of this type of arbitration.

\section{REFERENCES}

\section{A. Books}

Amiruddin, 2004, Pengantar Metode Penelitian Hukum, Raja Grafindo Press, Jakarta.

Bagheri, Mahmood, 2000, International Contracts and National Economic Regulation: Dispute and Resolution Through International Commercial Arbitration. Kluwer Law International, The Hague.

Berger, Klaus Peter, 2000, Understanding International Commercial Arbitration, Transnational Dispute Management, Center for Transnational Law ed.

Fitch, Ronald, 1989, Commercial Arbitration in the Australian Construction Industry, Federation Press, New South Wales.

Kansil, C.S.T, et al., 2005, Hukum Perusahaan Indonesia, Aspek Hukum dalam Ekonomi, Pradnya Paramitha, Jakarta.
Santoso, Topo, 2005, Penulisan Proposal Penelitian Hukum Normatif, Pelatihan Penelitian Hukum, Fakultas Hukum Universitas Indonesia, Depok.

Sanders, Pieter, 1975, Appeals Procedure in Arbitration' in International Commercial Arbitration, Documents and Collected Papers (1974-1975).

Saragih, R. F., 1999, Hukum dan Pembangunan, Lembaga Alternatif Penyelesaian Sengketa. Hukum dan Pembangunan.

Smit, Hans, et al., 2000, Commercial Arbitration: An International Bibliography $\left(2^{\text {nd }}\right.$ revised and expanded edition).

Sumaryono, Eugenius, 1993, Hermeneutik Sebuah Metode Filsafat, Kanisius Yogyakarta. 


\section{B. Journal Articles}

Arsic, Jasna, "International Commercial Arbitration on the Internet: Has the Future Come Too Early ?", Journal of International Arbitration, 1997.

Chukwumerije, Okezie, "Choice of Law in International Commercial Arbitration", Journal of International Marketing, Vol. 3, No. 2, 1995.

De Witt, Nicolas, "Online International Arbitration:

Nine Issues Crucial To Its Success", The American Review of International Arbitration, 2001.

Harpole, Sally A, "Factors Affecting the Growth (or Lack Thereof) of Arbitration in the Asia Region", Journal of International Arbitration, Vol. 20, No. 1, 2003.

Hill, Richard, "On-line Arbitration: Issues and Solutions", Arbitration International, Vol. 15, 1999.

Leahy, Edward, et al., "The Changing Face of International Arbitration", Journal of International Arbitration, Vol. 17, No. 4, 2000.

Yüksel, Armagan Ebru Bozkurt, "Online International Arbitration", Ankara Law Review, Vol. 4, No.1, Summer, 2007.

\section{Paper/Speech}

Budidjaja, Tony, "Public Policy As Grounds of Recognition and Enforcement Of Foreign
Arbitral Awards In Indonesia 154: the General Elucidation to Law of the Republic of Indonesia No.30 of 1999 concerning Arbitration and Alternative Disputes Resolution”, 2002.

Gautama, Sudargo, "Arbitrase Kamar Dagang Internasional", Paper, Raker Pertamina, Jakarta, 14 Oktober 1975.

\section{Internet Articles}

Manevy, Isabelle, "Online Dispute Resolution: What Future?", http://www.juriscom.net/uni/ mem/17/odr01.pdf, accessed at 20 August 2015 .

\section{E. Regulation}

Law No. 30 of 1999 on Arbitration and Alternative Dispute Resolution (State Gazzete of Indonesian Republic of 1999 No. 30, Supplement to State Gazzete No.3872).

Law No. 11 of 2008 on Information and Electronic Transaction (State Gazzete of Indonesian Republic of 2008 No. 58, Supplement to State Gazzete No. 4843).

President Decission No. 34 of 1981 on Ratification Convention on the Recognition and Enforcement of Foreign Arbitral Awards 1958 (the New York Convention). 